Meta

Journal des traducteurs

Translators' Journal

\title{
Discoursal Function of Phonological Patterns in Poetic Texts: Implications for (UN-) Translatability of Poetry
}

\section{Kazem Lotfipour-Saedi}

Volume 50, numéro 4, décembre 2005

Pour une traductologie proactive - Actes

For a Proactive Translatology - Proceedings

Por una traductología proactiva - Actas

URI : https://id.erudit.org/iderudit/019849ar

DOI : https://doi.org/10.7202/019849ar

Aller au sommaire du numéro

Éditeur(s)

Les Presses de l'Université de Montréal

ISSN

0026-0452 (imprimé)

1492-1421 (numérique)

Découvrir la revue

Citer cet article

Lotfipour-Saedi, K. (2005). Discoursal Function of Phonological Patterns in Poetic Texts: Implications for (UN-) Translatability of Poetry. Meta, 50(4).

https://doi.org/10.7202/019849ar
Résumé de l'article

Le texte poétique, en tant que genre littéraire, se distingue du texte non littéraire par son effet spécial sur le lecteur. On maintient que cet effet, dans son ensemble, constitue une des fonctions des formes littéraires superposées aux structures linguistiques ordinaires. Cet article se concentrera sur les structures phonologiques dans les textes poétiques.

Les structures phonologiques (rime, allitération, assonance, etc.), en tant qu'outils textuels, peuvent avoir des effets discursifs spéciaux. Cet article analysera quelques exemples de textes poétiques pour montrer comment des structures phonologiques peuvent mettre en valeur le thème par l'introduction de réseaux cohésifs " défamiliarisés " ou " déshabitués " par le texte et par la répétition des concepts introduits par le contexte lexical des structures phonologiques. On examinera ensuite les implications pour la (non-) traductibilité des textes poétiques. La traduction de la poésie n'est pas uniquement la production d'un texte en langue cible contenant des structures à rimes. Le texte en langue cible doit aussi être équivalent au texte en langue source en termes de type et de degré d'effets spéciaux littéraires. Dans ce but, les structures à rimes, en raison de la fonction textuelle particulière qu'elles remplissent dans la poésie, doivent être placées dans le même contexte lexical en langue source et en langue cible, exigence qui ne peut être que difficilement obtenue à cause du non-isomorphisme de la relation son-sens entre les langues.
Ce document est protégé par la loi sur le droit d'auteur. L'utilisation des services d'Érudit (y compris la reproduction) est assujettie à sa politique d'utilisation que vous pouvez consulter en ligne.

https://apropos.erudit.org/fr/usagers/politique-dutilisation/ 


\title{
Discoursal Function of Phonological Patterns in Poetic Texts: Implications for (UN-) Translatability of Poetry
}

\author{
KAZEM LOTFIPOUR-SAEDI \\ University of Ottawa, Ottawa, Canada \\ klotfipour_saedi@hotmail.com
}

\begin{abstract}
RESUME
Le texte poétique, en tant que genre littéraire, se distingue du texte non littéraire par son effet spécial sur le lecteur. On maintient que cet effet, dans son ensemble, constitue une des fonctions des formes littéraires superposées aux structures linguistiques ordinaires. Cet article se concentrera sur les structures phonologiques dans les textes poétiques.

Les structures phonologiques (rime, allitération, assonance, etc.), en tant qu'outils textuels, peuvent avoir des effets discursifs spéciaux. Cet article analysera quelques exemples de textes poétiques pour montrer comment des structures phonologiques peuvent mettre en valeur le thème par l'introduction de réseaux cohésifs «défamiliarisés» ou «déshabitués» par le texte et par la répétition des concepts introduits par le contexte lexical des structures phonologiques. On examinera ensuite les implications pour la (non-) traductibilité des textes poétiques. La traduction de la poésie n'est pas uniquement la production d'un texte en langue cible contenant des structures à rimes. Le texte en langue cible doit aussi être équivalent au texte en langue source en termes de type et de degré d'effets spéciaux littéraires. Dans ce but, les structures à rimes, en raison de la fonction textuelle particulière qu'elles remplissent dans la poésie, doivent être placées dans le même contexte lexical en langue source et en langue cible, exigence qui ne peut être que difficilement obtenue à cause du non-isomorphisme de la relation son-sens entre les langues.
\end{abstract}

\begin{abstract}
Poetic text, as a literary genre, is distinct from non-literary text because of the special effect it can have on the reader and this special effect in literature-text, as a whole, has been argued to be a function of the special literary forms imposed upon the ordinary language patterns in the literaturetext. Among these special forms, this paper will focus on phonological patterns in poetic texts.

Phonological patterns (rhyming, alliteration, assonance, etc.), as special textual tools, can be argued to achieve various special discoursal effects. This paper will analyze a few pieces of poetic text to demonstrate how the phonological patterns employed in them could enhance the textual theme by introducing "defamiliarized" or "dehabitualized" cohesive networks across the text and by reiterating the concepts introduced by the lexical locality of the phonological patterns. The paper will then discuss the implications for the (un-) translatability of poetic texts. Translating poetry does not merely mean producing a text, in TL, which carries rhyming patterns. The TL text should also be equal to SL in terms of the type and degree of special literary effect. For this purpose, the rhyming patterns, due to the special textual function they assume in poetry, should be placed upon the same lexical locality in both SL and TL, a requirement which can hardly be achieved due to the non-isomorphism of sound-meaning relationship across languages.
\end{abstract}

\section{MOTS-CLÉS/KEYWORDS}

literature-text, phonological patterns, discoursal effects, poetry

\section{Introduction}

Discoursally speaking, translation equivalence should be defined in terms of the availability of the SL discoursal resources through the TL textual tools to the TL reader as if the reader is interacting with the SL producer. Since due to the importance of the form and "way of saying" in literature- 
text, especially in poetry, the border line between discourse and text or "what is said" and "the way it is said" disappears and form assumes as much significance as meaning, translation of poetic texts poses a real challenge. To demonstrate this, we shall look at a Persian sonnet analyzing the way its special rhyming patterns contribute to the discourse process and discussing the obstacles encountered in their translation.

\section{Translation: an Act of "Relaying" not "Conveying"}

According to the discoursal view of language, meanings and messages are not carried in their pretailored and ready-made shape by texts; they are interactively and "dialogically" (Bakhtin 1981) negotiated by the participants; and texts act only as interface mediators between the producer and receiver discourse processes. Thus, the message to be negotiated from a text would depend not only on the text factors but also on the receiver factors including the amount of orientation background knowledge.

Translating as an act with the intention of making a text in one language accessible to the speakers of another language cannot, thus, be defined in terms of "replacement" (Lotfipour-Saedi 2000) of SL elements (forms and meanings) by "equivalent" TL ones. Firstly, languages, as "unique structural systems" (Saussure 1959) cannot all be said to possess the same forms; secondly, the relationship between "forms" and "meanings" is not of the same pattern; and last but not least, as noted above, meanings are not "carried" or "conveyed" by the texts.

On the basis of this view of language, we define translating as an act of "relaying" the SL discoursal conditions to the TL reader so that they (SL text author and TL receiver) can interact with one another directly and we characterize translation equivalence accordingly along certain "aspects of textual structure" and "dimensions of discoursal value" (Lotfipour-Saedi : forthcoming).

Among the aspects of textual structure for the characterization of translation equivalence (TE), the following can be cited: vocabulary, structure, texture, language variety, extraneous linguistic choices, prominent linguistic choices and paralanguage. Any variation in any of these aspects of textual structure and the fact that languages may vary in both form and meaning of these aspects should be taken into account by the translator.

As for the dimensions of discoursal value, it should be said that texts may vary not only in terms of any of the aspects of textual structure (just named above), but also in terms of the discoursal values represented by them. In fact, according to the discoursal view of language, any, even a minor variation in the textual structure, is motivated by the underlying discoursal factors. The following dimensions of discoursal value can be named: "degree of indrectness in saying", "degree of indeterminacy of the message", "cognitive effect and the degree of comprehensibility" and "literary effect" (Lotfipour-Saedi: forthcoming).

\section{Literature-Text and Literary Effect}

Literature belongs to a distinct universe of discourse; this distinction is mainly in terms of the "distinct" or rather "special" effect literature-text can produce on the reader. But the "special" effect in literature is due only to the special patterning of language patterns (Hasan 1985). These special patterns have been isolated by different authors in terms of graphological, phonological, syntactic and semantic patterns (Cummings \& Simmons 1983 \& Widdowson 1975). Parallel to his characterization of a text as the embodiment of a set of discoursal and textual strategies, Lotfipour-Saedi (1990) describes a literature-text as embodying special discoursal and textual strategies superimposed upon the ordinary ones. He points out three special discoursal strategies, i.e. indirection, dehabitualization and indeterminacy, which, he says, are represented through special textual strategies such as rhyming, alliteration, irony, metaphor, structural parallelism. It has been argued that the special patterns employed by a literary producer would contribute to the literary effect of that text by rendering the discourse more indeterminate, indirect and defamiliar. The focus of this paper will be on the special phonological patterns in poetic texts, examining their discoursal value and discussing whether / how they can be taken care of in the translation process. 


\section{Phonological Patterns in Poetry: Speculations on Their Discoursal Function}

Phonological patterns in poetic texts are not merely decorative, playing no discoursal role in the host text. They rather function as "defamilarized" textual strategies, contributing to the texture of the text thereby affecting the socio-cognitive dimensions of the discourse process. Phonological patterns may be classified into two major categories as follows: text-independent and textdependent.

- Text - independent: These are special sound patterns which are independent from the text in which they occur and would achieve their discoursal effect no matter where in the text they are located. As an example, we may cite lullabies which would perform their function of "soothing" young babies to sleep without the receiver knowing the language or having acquired any. Lullabies have, in fact, been investigated to be universal in their effect, i.e. lullabies in one language having similar effect on the recipient children of different linguistic backgrounds (Hasan 1985). The reason for this, it may be argued, lies in the fact that their effect arises only from the special combinations of the language sounds and their lexical locality plays no role here.

- Text - dependent: These are special sound patterns which would depend on the text and the lexical locality on which they occur to achieve their discoursal effect. Rhyming and sound patterns as abnormal and "defamiliarized" textual strategies, due to the sound similarities they spread over the lexical items of their locality, create in the mind of the reader special links among the senses of their respective lexical location, thereby activating a special discourse process super-imposed upon the ordinary one. Thus both the text and discourse here are of a special nature. The sound similarities lead to special textual links, which in turn set the concepts activated by such links into interaction in the mind of the reader allowing him/her to engage in an extra meaning-negotiation process on the basis of his/her sociosemiotic resources. Referring to Roman Jakobson's views on the relationship between sound and meaning in poetic texts, Folkart (2003: 488) notes that "similarities at the level of sound set up similarities or dissimilarities at the level of sense" and argues that "similarity of sound between items in the working memory predisposes the reader to couple the items semantically as well". In fact, Folkart believes that "the pregnancy of rhyme and rhythm" is one of the things that so strongly distinguish poetry from light verse. She cites a piece of poetry from Stallworthy:

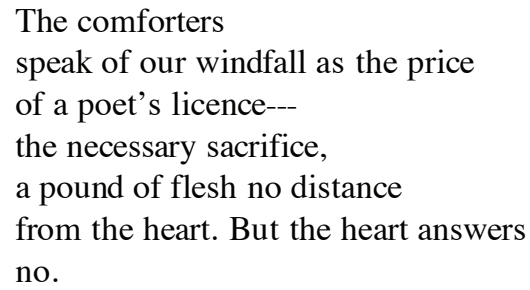

where, she argues, the poet's "rhyme-words ---phonetically subtle, semantically rich, less simplemindedly spaced---build into a music that's entirely in the service of what the poem has to say : license and distance echo the wrenching coupling of chance and providence in an earlier stanza" (Folkart 2003:488) .

Folkart refers to the effect of rhyme on meaning as valency of rhyme and defines it as "the extent to which phonetic overlap induces a semantic overlap that contributes to the construction of the poem's truth value" (p.488).

To further illustrate the effect of this second type of sound patterns on the poetic meaning, we shall look at a Persian Sonnet examining the textual and discoursal functions of its rhyming patterns. This Sonnet consists of ten lines (couplets) each containing two verse. At the end of each couplet or line, the phrase "Gham-makhor" (meaning "do not grieve") is repeated; and this 
phrase is always preceded by a rhyming pattern "- aan" (a word ending in "-aan"). The same combination is repeated at the end of the first verse (half-line) too.

The repetition of this combination (of the rhyming element followed by the same phrase: / ........--aan gham makhor / can be seen as a special textual strategy reiterating the concepts denoted by the lexical locality of the rhyming element "-aan". Halliday and Hasan (1976) in their discussion of the cohesive "agencies" or "ties" which contribute to the texture of a text name three major categories: grammatical cohesion, lexical cohesion and conjunction. For lexical cohesion, they name two basic categories: "collocation" and "reiteration". By "reiteration", they mean the way concepts introduced at the earlier stages of the textual unfolding are later repeated and they name different strategies for this repetition: "repeating the same word", "synonyms", "u sing a super-ordinate word", "using a general word" or "using a proform" (Halliday \& Hasan 1976 and Halliday 1985).

"Reiteration" as a cognitive strategy is one of the essential requirements of interpersonal verbal interactions. The reason for reiterations in the textual presentation of the discourse process is that texts as mediators in this transaction are linearly organized; and because of the limitations of human cognitive and memory (both STM and LTM) capacity, this textual organization represents only parts of the discourse in the receiver's working memory. But for the addressee to be able to negotiate a message, he/she should be able to visualize the whole discourse in its totality and process the linearly received text in terms of this discoursal totality. Reiterations are one of the textual strategies which help resolve this paradox. They re-activate the elements and concepts introduced in the earlier stages to the receiver's working memory allowing him/her to access a more comprehensive and wider picture of the discourse. Literature-text, as we noted above, embody some special and "unfamiliar" textual and discoursal strategies apart from the ordinary ones. Reiteration, as a textual strategy, may also assume special forms in literature. The rhyming pattern in the Sonnet we discussed above can be an example of special reiteration strategies in poetic texts.

The whole sonnet consists of a set of "scenarios" punctuated by the rhyming patter introduced above: "........-aan gham makhor":
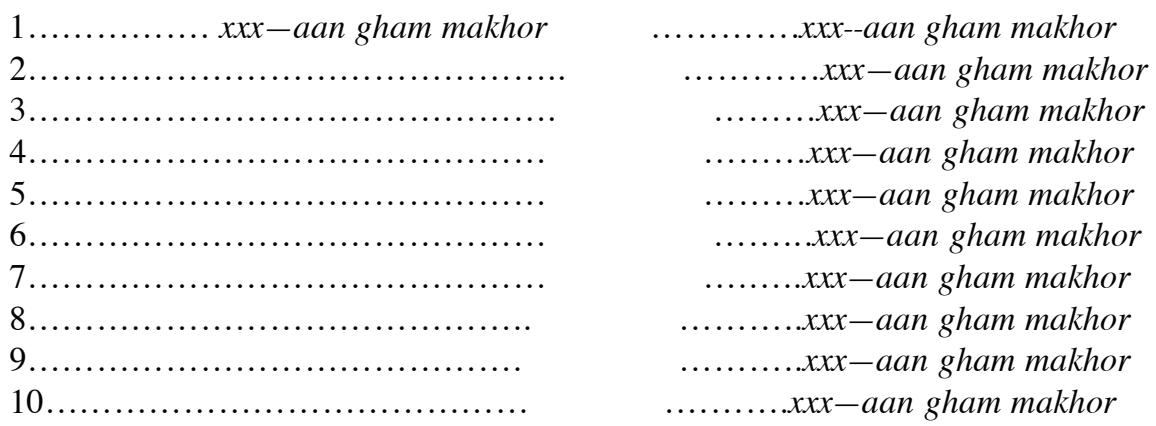

Each "scenario" includes one or more images and the reader's engagement in the transactions of the scenarios would depend on his/her socio-semiotic as well as intertextual familiarity with those images. The discoursal coherence of the whole Sonnet should be defined in terms of the uni-directionality of the events in the scenarios (see Leech 1970 for his notion of "cohesion of foregrounding" and Butt 1984 for his notion of "ideational drift", which are similar to our notion of "uni-directionality"); and the reader's perception and appreciation of this coherence would depend on his/her socio-semiotic and intertextual knowledge. The rhyming points or the lexical items which occur in the slot indicated by "xxx" in the rhyming pattern " $x x x-a a n$ gham makhor", apart from their normal lexico-grammatical roles, would perform two special discoursal functions: syntagmatically and paradigmatically:

- Syntagmatically: Depending on its lexico-grammatical function, the item constitutes a syntagm out of the textual elements presented in each line before it; and the scenario activated would depend on this syntagm. 
- Paradigmatically: Each rhyming point, in the light of the sound similarity it has with the others, would reiterate, upon its perception, all the other rhyming points together with the syntagms which are dragged along with them. Thus, the rhyming patterns act as special reiteration strategies, reactivating the previously-presented scenarios throughout the textual perception; and the number of reiteration of each scenario would vary according to its place in the text: the farther back from the point of perception it is located, the more the number of its reiterations. This reiteration system enables the reader to revive all the scenarios (and thereby the whole discourse) as a paradigm to his/her working memory and to have access to them. Through this paradigmatic link mediated by the rhyming pattern across the scenarios, a special discourse process (as a foreground for the discourse process represented by the ordinary text) is set in motion for a special literary meaning to be negotiated by the reader.

The lexical localities of the rhyming patterns play a significant role in these syntagmatic and paradigmatic textual operations:

- Syntagmatically, depending on their lexico-grammatical identity (process, participant etc), the lexical localities of the rhyming patterns will exert varying degrees of cohesive influence on the syntagm, affecting the degree of recallability.

- Paradigmatically, the lexical localities provide the route through which various scenarios can be accessed and a gate through which they can engage in interaction with one another.

The lexical localities of the rhyming patterns would, thus, assume a role similar to the one specified for the thematic elements in systemic functional grammar (Halliday 1985 and LotfipourSaedi \& Razaii-Tajani 1996). They determine the contents of the reader's working memory and the angle from which the paradigmatically arranged scenarios should be set in interaction with one another.

\section{Rhyming Patterns in Translation}

We defined translation as an attempt to relay or recreate the conditions under which the SL writer and TL receiver can interact with one another. We also looked at literature-text where the borderline between "what is said" and "the way of saying" collapses and "how" or "way of saying" becomes "what". One of the "special" ways of saying in poetic text rhymes; and as we demonstrated above, rhyming patterns, as special textual strategies, play significant discoursal role in most poetic texts. They should, thus, be taken care of in the translation process if the translator wants to preserve the same literary effect intended by the SL author. But how can this are achieved?

Taking care of "rhyming patterns" in the process of translating a poetic text does not merely mean that the TL text should also carry rhyming patterns. Translation equivalence in literature in general and in poetic text in particular should be viewed in terms of the SL special literary effect mediated by the special "dehabitualized" textual strategies. To guarantee that the TL reader will be exposed to a special literary universe of discourse similar to the SL one, the translator should attempt to "relay" the same or parallel textual strategies (ways of saying) in TL. For example, metaphors should translate into metaphors, similes into similes, rhyming patterns into rhyming patterns. "Relaying" here would imply that the TL forms should be of the same discoursal value as their parallel SL ones. The "sameness" condition is the least possible in the case of rhyming patterns because, firstly languages are not isomorphic in terms of their form-meaning relationship and as such the lexical items acting as the base of a rhyming pattern in one language will more probably not do so in another language and any change in the locality of the rhyme will lead to a change in the discoursal effect due to possible changes in the lexico-grammatical identity of the rhyming bases and the "syntagms" and "paradigms" they activate to the working memory of the reader; and secondly poetic forms and rhyming norms vary across languages. For example, the Persian Sonnet forms and the rhyming patterns they employ are specific to Persian. 
Due to the special nature of poetic texts, especially those of highly literary value, this paper, rather than looking at how poetic texts should be rendered by the translators, tried to come up with justifications for their untranslatability.

\section{REFERENCES}

BAKhtin, M. M. (1981): The Dialogic Imagination: Four Essays by M. M. Bakhtin, Holquist, M. (ed.), translation by EMERSON, C. \& M. HolQuist, Austin, University of Texas Press.

ButT, D. (1984): "To Be Without a Description of To Be", The Relationship Between Theme and Lexicogrammar in the Poetry of Wallace Stevens, unpublished $\mathrm{PhD}$ thesis, Sydney, Macquarie University.

Cummings, M. \& R. Simmons (1983): The Language of Literature : A Stylistic Introduction to the Study of

Literature, London, Pergamon Press.

FolKart, B. (2003): “The Valency of Poetic Imagery”, in PetriLli, S. (ed.): Translation Translation,

Amsterdam, Rodopi, p. 487-506.

HallidAy, M. A. K. (1985): An Introduction to Functional Grammar, London, Edward Arnolds.

HALlidAy, M. A. K. \& R. HASAN (1976): Cohesion in English, London, Edward Arnolds.

HASAN, R. (1985): Linguistics, Language and Verbal Art, Victoria, Deakin University Press.

LEECH, G. N. (1970): “'This Bread I Break' -Language \& Interpretation”, in FreEMAN, D. C. (ed.): Linguistics \& Literary Style, New York, Holt, Rinehart \&Winston Inc.

LotFiPOUR-SAEDI, K. (1990): "Discourse Analysis and the Problem of Translation Equivalence", Meta 35-2, p.

389-397.

LotFIPOUR-SAEDI, K. (2000): "Element-for-Element Replacement? Beware! There Might Be a No-Entry Sign",

Meta 45-4, p. 622-627.

LOTFIPOUR-SAEDI, K. (forthcoming): Discourse and the Act of Translating: A Discoursal Approach to the

Characterization of Translation Equivalence.

LOTFIPOUR-SAEDI, K. \& F. REZAII-TAJANI (1976): "Explorations in Thematization Strategies and Their Discoursal Values in English", Text 16-2, p. 225-249.

De SAussure, F. (1959): A Course in General Linguistics, translation by BASKIN, W., New York, McGraw-Hill

Book Co.

WidDOwSON, H. G. (1975/1984): Stylistics and the Teaching of Literature, London, Longmans. 